\title{
15
}

\section{The Supply chain Perspective of e-business Evolution}

\author{
V. Manthou, M. Vlachopoulou, D. Folinas \\ University of Macedonia, Department of Applied Informatics
}

\begin{abstract}
Companies regard supply chain as a medium for achieving short-term economic benefits and gaining long-term competitive advantages. It comprises the recognized discipline for shortening cycle times, transforming purchasing from a tactical operation to strategic sourcing, reducing inventories, and decreasing logistics costs. Furthermore, it streamlines communication processes across a total network, from initial supplies to final consumption and post-sale customer service. Specialized human power, appropriate and integrated processes and new technologies are the supply chain's pivots. The focus of supply chain management has shifted from engineering efficient functional processes to the coordination of activities in a supply chain network through knowledge management. In this paper e-business and supply chain transformation interdependency is examined through a four-stage approach. A supply chain grid is developed and specific key elements are classified providing a useful roadmap for the planning and/or evaluation of supply chain transformation levels in practice.
\end{abstract}

Keywords: e-Business, e-logistics, supply chain management

\section{INTRODUCTION}

In today's e-business environment forces like global competition, increased information availability, customer focused marketplaces, and the emergence of the knowledge society require a new orientation of supply chain management

\footnotetext{
The original version of this chapter was revised: The copyright line was incorrect. This has been corrected. The Erratum to this chapter is available at DOI: 10.1007/978-0-387-35617-4_48 
shifting from a linear, sequential supply chain to an adaptive supply chain network.

The concept of supply chain refers to activities of procurement, order fulfilment, product design and development, distribution, delivery, shipping and customer service, executed by two or more separate organizations, to fulfil customer orders. Supply chain management's goals are the coordination of each tier's activities, as well as between tiers, in order to facilitate the smooth and efficient flow of products down the value-added chain at the least cost and delivery time, matching the supply with the market demand (Tan et al., 2000, Lipis, Matthews, 2001). With the dramatic effect of new information and communication technologies supply chain management can also be regarded as a mechanism through which diverse and geographically dispersed companies find a way to create alliances to meet a new form of Internet-oriented consumer demand. These alliances are advanced and dynamic networks that move forward, with their resources focused on bringing elements of e-business to specific market segments in order to be in a leader market position.

Although the establishment of e-supply chain systems, in order to create the necessary links among data, applications, and logistics processes, between partners and customers, is considered of central importance, the supply chain dimension of e-business revolution is largely neglected, poorly designed and managed (Hoek, 2000).

The scope of this paper is to analyse the relevance of e-business evolution from a supply chain perspective. Specifically, e-business and supply chain transformation interdependency is examined through a four-stage approach. A supply chain grid is proposed thus, providing a useful roadmap for identifying specific key elements and dimensions for future development or current evaluation of supply chain management practice.

\section{E-BUSINESS AND SUPPLY CHAIN INTERDEPENDENCY}

There is a total dependence between e-business and supply chain approaches. Both of them have a common base line, the Net. Information technology, and in particular, the Internet, plays a key role in furthering the goals of supply chain optimization. While the most visible manifestation of the Internet has been in the emergence of electronic commerce as a new marketing channel, it is likely that the Internet will have an even more profound impact on the area of supply chain management. 
The Internet environment blurs geographical boundaries, promotes dynamic networks, favors customer-centric offerings, and compresses cycle times. It can redefine how back-end operations, product design and development, procurement, production, inventory, distribution, after-sales service support, and even marketing, are conducted and in the process alter the roles and relationships of various parties, fostering new supply networks, services and business models. According to Arthur Andersen survey, main problems experienced with on-line purchasing, and related to supply chain performance are: "gift wanted to purchase was out of stock, product was not delivered in time and paid too much for the delivery" (Andersen, 2000).

The general key attributes of trends recognized by the swing toward e-supply chain transformation influenced and supported by e-Business evolution are presented in figure 1 and are further analyzed and categorized in section 4 . In order to further support the realization of e-business objectives through supply chain, relevant innovative practices must be established. Emerging distribution channels are required to support new, dynamic consumer requirements. As a result, traditional supply chain boundaries are disappearing. Manufacturing, marketing, distribution, and transportation are merging into a single process, creating an urgent need for integration and transformation.

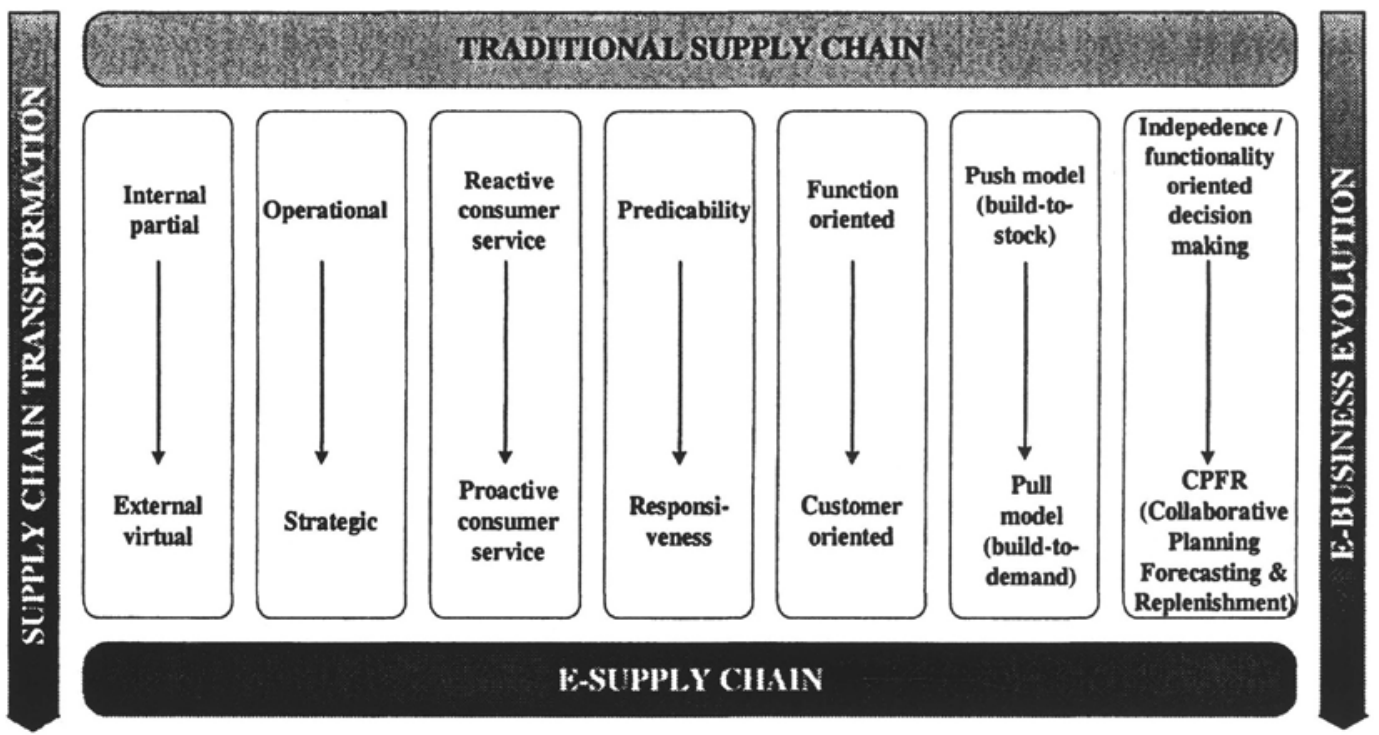

Figure 1. Trends of Supply Chain Concept

Thus, new web-based business networks are established replacing the linear supply chain model characterized by global visibility of customer, product, or 
supply information throughout the supply chain, enhanced customer relationships leading to repeat business through fast, accurate product delivery, and professional customer response services and coordinated, rapid decisionmaking environment that synchronizes the global supply chain.

\section{1 e-Business evolution}

The continuous attempt to improve the enterprise supply chains follows chronically -as will be mentioned further on- the evolution of e-business. Internet analysts (Morath, 2000) agree on four stages of business involvement in Internet. They discriminate among: brochureware, e-commerce, e-business and e-enterprise stages. Some others refer to the phases as: batch EDI (community meeting place), basic e-commerce (catalog-merchandising listing), community commerce (commerce transactions) and collaborative commerce. Tom Vassos (1996) suggests three phases of web business development: foundation, extension and transformation. Ernst and Young (1999), looks on three phases of business penetration in web too, based on the related strategic goals: presence, penetration and profits.

According to Gartner Group (2000) there are four phases of transition from the first applications of e-commerce to the complete e-business strategiessolutions. These phases are defined based on the technologies used, the services offered and supported and the level of data information exchange.

Presence: Basic presence with static content, including graphics and information about company and its products and services.

Interaction: Catalog orders, consumer services, establishment of an online communication channel, which delivers targeted information to customer segments or specific partners, through an interactive content. Web site is used for marketing.

Transaction: Initial B2B functionalities through home page focusing on transactions and sales facilitation. Moderate integration of core systems (ERP, SCM) with Internet applications (often via intranet). Customer specific applications become more prominent with full interactivity. Sales, distribution, auctions, business-to-business interactions.

Transformation: Full functionalities and systems integration. Web services connect applications and processes. Intelligent agents, web analytics, customeroriented products and sophisticated cross-selling applications alter web site in a virtual self-existence enterprise. Complete realization, acceptance and implementation of Internet capabilities transform the whole business strategy. 
Business-to-business processes, direct digital customer contact. SCM optimization and full information visibility among customers using CRM systems, among partners using PRM systems.

\subsection{Supply Chain transformation phases}

From World War II until the 1970s, the logistics business primarily concentrated on basic transportation service. The 1980s saw the advent of timedefinite delivery as UPS, Federal Express and other transportation industry providers began to guarantee delivery times. Early in the 1990s, more companies began to outsource their warehousing and fulfilment needs to third-party logistics (3PL) providers, which created added value through multi-client leverage. During the same period, 3PLs also began to offer arrangement of transportation and distribution services.

Finally, we are beginning to see companies offering total integrated logistics services that address the warehousing, transportation and information technology needs of the supply chain. The information management capability is the foundation for the e-supply chain evolution. The customer now expects webbased order-status tracking capabilities, electronic proof-of-delivery, postponement manufacturing and postponement services, call centre and webbased customer service, self-service and, finally, personalized interaction.

As far as the evolution of the supply chain is concerned, there are many views. Some analysts support that the evolution goes through three (Burnes, 1996, LaLonde, 1998, Muzumdar and Blachandran, 2001), four (Straus, 2002), or five phases (Poirer and Bauer, 2001), (Durchslag et al., 2001), (Stein, 2001). In order to map temporally the evolving phases of e-business with the corresponding phases of supply chain optimization, we consider that the latter consists of the following phases: core logistics activities efficiency, coordination of internal organizational processes, inter-enterprises of business exchanges, and establishment of dynamic networks between virtual organizations.

Core logistics activities efficiency

Some analysts refer to this phase as 'fundamental' or 'inception' (Dobbs, 1998, Poirer and Reiter, 1998). This phase represents company's first effort of application of supply chain techniques by pursuing logistics improvements in specific activities, mostly by leveraging its total volume over a smaller base of suppliers. Better quality, lower prices, inventory reductions, lower costs are accomplished in this level. Each functional area or department plans and operates in an isolated environment.

Coordination of internal organizational processes 
Cross-functional and cross-business unit cooperation arises in order to achieve internal excellence. The seeds of e-commerce are planted in this level, as companies develop internal information support system (intranet) and enterprise systems that enable further supply chain progress. Supply chain planning and execution decisions are taken enterprise-wide.

Inter-enterprises of business exchanges

In this phase companies' orientation moves to a dynamic model and balancing internal improvement with the external needs of the full supply chain network. External resources are added to internal teams seeking network improvement and satisfaction of the consumer. Transition of supply chain from a push model toward the consumer, to a condition in which the consumer is pulling the product / service via actual demand is noticed. Business-to-business innovative models arise by establishing value chain constellations. This stage starts to shift to a more outward customer focus and the ability to connect directly to external partners and customers (value chain constellation). In this phase cross-functional teams balancing internal improvement with the external needs of the full supply chain network drive supply chain management.

\section{Establishment of dynamic networks between virtual organizations}

Development of e-supply collaborative models and full network connectivity between virtual enterprises characterizes this phase. Advanced supply chain management concepts can be established and used in order to optimize the use of mutual assets, to reduce costs to a feasible minimum, and surpass consumer expectations. An external and dynamic environment in which supply chain optimization and e-business applications really blossom is developed. The convergence of both efforts leads to the e-business models that will help a company and its partners to achieve market dominance. At this stage communities or marketplaces or supply chain synergies are created (Poirer and Bauer, 2001, Durchslag et al., 2001). The enterprises establish among them supply chain networks with common aims and objective goals. The dynamic nature of the enterprise network gives a significant competitive advantage at the participating enterprises and renders them capable to cope with the new conditions of the global market (Simchi-Levi et al., 2000, Kulin and Rosenbaum, 2000). Emphasis is given on the high level of information and processes integration among members (Pfohl and Buse, 2000, Sydow, 1996, Hinterhuber and Levin, 1994, Folinas et al., 2001). Through collaboration, supply chain partners can become involved in such processes as advanced planning and scheduling, demand planning and scheduling, or inventory 
management (Hamel and Prahaland, 1990). Collaboration is where the virtual supply chain networks possibilities come alive.

\section{SUPPLY CHAIN TRANSFORMATION GRID}

The dynamics of supply chain scope and orientation in relation to e-business applications deployment is reaching several levels of supply chain management transformation. Their distinction is marked by the degree ("low" to "high") and the focus of e-business applications ("content and communication" versus "transaction") and the supply chain management scope (serving single or multiple markets based on operational or strategic information/decisions orientation). Each of the four quadrants in the supply chain transformation grid (Figure 2) provides a useful framework for identifying specific key elements and dimensions for future development or current evaluation of supply chain management practice. The main characteristics for each quadrant are determined and some practical examples are mentioned, taking though into consideration that the limits between them are fluid.

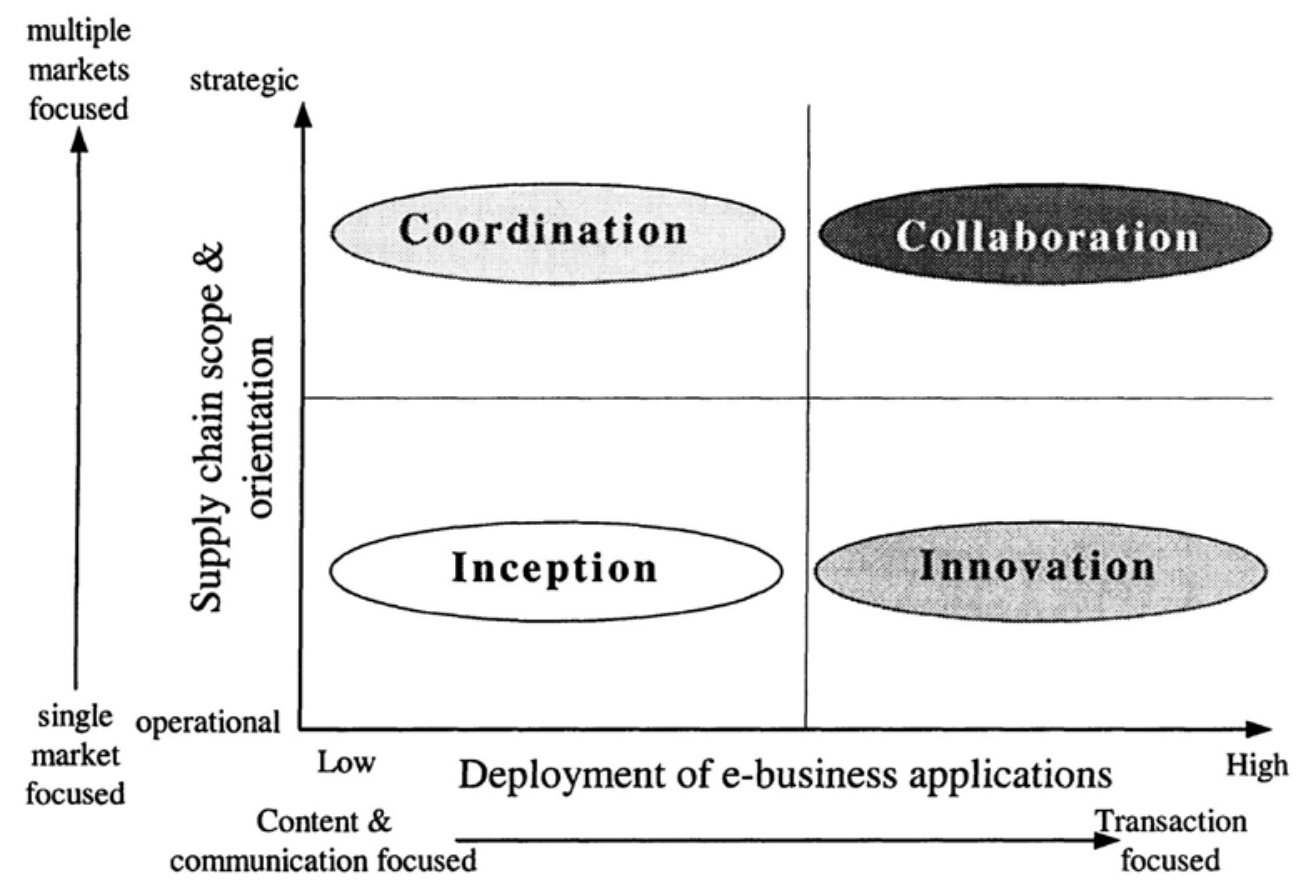

Figure 2. Supply Chain Transformation Grid 
Inception: core logistics activities efficiency

In this quadrant, information sharing or data exchange are the main ebusiness applications, which can support the realization of supply chain objectives. Supply chain partners or customers needs, can share various types of information including suppliers' offerings or customers, either before or after a purchase is made. The data/information is used by the recipient as it is by accessing/or transmitting shared information and does not provide feedback. That means there exists one directional information flow providing little opportunity to partners' interaction on matching supply with anticipated customer demand. Examples of companies in this quadrant are logistics vendors and vortals.

Coordination: internal partners / customers interaction

In this quadrant individual supply chain partners start to interact with each other and determine prices and availability of goods and services, as well as delivery terms. Successful negotiations are usually finalized with a contract. Business paradigms of this quadrant are: 3-4 PL's like UPS Worldwide Logistics (http://www.ups.com), FedEx (http://www.fedex.com) etc. or non PL's such as GM's Service Parts Division (http://www.gm.com), PricewaterhouseCoopers \& THOMSON / (http://www.pwcglobal.com/).

Innovation: e-settlements, e-exchanges, value chain constellations

Innovative Internet technologies deal with electronic transactional aspects of supplier/customer relationships. Thus, automation has focused on send purchase orders and invoices and on transfer funds. The only information that must be transmitted in this type of relationship is that needed to execute a purchase. Value chain constellation is applied in an operational manner and in segments of supply chain only, as opposed to a dynamic virtual network approach, that of strategic and integral supply chain involvement. Leading companies such as National Semiconductor (http://www.national.com), Seagate (http://www.seagate.com), AMD (http://www.amd.com), Siemens (http://siemens.com), JVC (http://jvc.com), Toshiba (http://toshiba.com), Toyota Co. (http://toyota.com) and Hitachi (http://hitachi.com) are some examples of this quadrant.

\section{Collaboration: dynamic and integrated virtual networks}

Collaborative virtual networks enable trading partners to work together on new products design, customer demands forecasts, based on real time visibility across the entire supply chain, flexibility of supply and sourcing options, and customer responsiveness (build on demand). Smart Car, 
(http://www.smart.com/), Coca-Cola Bottling (http://www.coke_cce.com/), Baker Street Technologies (http://www.bakerstreettech.com), Lexmark Electronics, (http://lexmark.com), SciQuest.com (http://www.sciquest.com), Motorola (http://www.motorola.com), are some of typical examples of collaboration.

\section{CLASSIFICATION OF SUPPLY CHAIN LEVELS}

The four levels of supply chain transformation, according to the grid presented in this paper, are classified based on specific key elements in relation to the following dimensions: business strategy, customer and partnership relationships, technology implementation and information / decision making orientation (Figures 3,4). These figures can be used as a roadmap for the planning and / or evaluation of supply chain transformation levels in practice. 


\begin{tabular}{|c|c|c|c|c|}
\hline Key element & Inception & Coordination & Innovation & Collaboration \\
\hline
\end{tabular}

\section{PARTNER \& CUSTOMER RELATIONSHIPS DIMENSIONS}

\begin{tabular}{|c|c|c|c|c|}
\hline Trust & None or limited & Low & High & IIigh \\
\hline Shared values & One-way communication & $\begin{array}{l}\text { Access in central } \\
\text { database }\end{array}$ & $\begin{array}{l}\text { Data \& information } \\
\text { exchange }\end{array}$ & Sharing processes \\
\hline Customer service & Reactive & $\begin{array}{l}\text { Interacted (forms, } \\
\text { bulletin boards, FAQ's, } \\
\text { catilogs, e-mails) }\end{array}$ & $\begin{array}{l}\text { Antomated firontend } \\
\text { CRHB }\end{array}$ & $\begin{array}{l}\text { Based on knowledge } \\
\text { management } \\
\text { (analy tical CRM) }\end{array}$ \\
\hline Reach & Business unit & Enterprise & Extended enterprise & Global interface \\
\hline $\begin{array}{l}\text { Market } \\
\text { transparency }\end{array}$ & Low, fixed supplier base & $\begin{array}{l}\text { Low, no centralized } \\
\text { market }\end{array}$ & $\begin{array}{l}\text { High, inter-enterprise } \\
\text { transparency }\end{array}$ & $\begin{array}{l}\text { High, inter-enterprise } \\
\text { knowledge } \\
\text { management }\end{array}$ \\
\hline $\begin{array}{l}\text { Partner } \\
\text { relationships }\end{array}$ & $\begin{array}{l}\text { Win-lose interactions } \\
\text { with vendors }\end{array}$ & $\begin{array}{l}\text { Arms-length } \\
\text { relationships }\end{array}$ & $\begin{array}{l}\text { Joint veatures, pertial } \\
\text { alliances }\end{array}$ & $\begin{array}{l}\text { Collaborative } \\
\text { relationships }\end{array}$ \\
\hline $\begin{array}{l}\text { Level of } \\
\text { customization / } \\
\text { standardization }\end{array}$ & $\begin{array}{l}\text { Pure or segmented } \\
\text { standardization }\end{array}$ & $\begin{array}{l}\text { Customized } \\
\text { standardization }\end{array}$ & Tallored customization & Pure customization \\
\hline
\end{tabular}

\section{INFORMATION / DECISION MAKING DIMENSIONS}

\begin{tabular}{|c|c|c|c|c|}
\hline $\begin{array}{l}\text { Planning and } \\
\text { execution } \\
\text { decisions }\end{array}$ & $\begin{array}{l}\text { Silo-based, by functional } \\
\text { managers \& key } \\
\text { associates based on } \\
\text { limited information } \\
\text { visibility \& } \\
\text { standardimation }\end{array}$ & $\begin{array}{l}\text { Business process focus, } \\
\text { medlum effectiyeness } \\
\text { because of limited } \\
\text { standardiontion of } \\
\text { Information across the } \\
\text { enterprise, integrated } \\
\text { cross-functional } \\
\text { decisions, limited } \\
\text { collaboration }\end{array}$ & $\begin{array}{l}\text { Extension planaige } \\
\text { process bejoud } \\
\text { enterprise, lizaited } \\
\text { collaboration }\end{array}$ & $\begin{array}{l}\text { Collaborative design, } \\
\text { plamning \& demand } \\
\text { forecasting, virtual } \\
\text { network life-cycle } \\
\text { management, } \\
\text { collaborative } \\
\text { pro-active decisions }\end{array}$ \\
\hline $\begin{array}{l}\text { Share of } \\
\text { information }\end{array}$ & $\begin{array}{l}\text { Decentralized, } \\
\text { functional, departmental }\end{array}$ & $\begin{array}{l}\text { Internal, centralized } \\
\text { (for corporate } \\
\text { planning) }\end{array}$ & $\begin{array}{l}\text { Rrternal, information } \\
\text { sharing with vendors } \\
\text { and customers }\end{array}$ & $\begin{array}{l}\text { Full sharing \& } \\
\text { information visibility } \\
\text { real-time collaboration }\end{array}$ \\
\hline Decision making & Based on historical data & $\begin{array}{l}\text { Based on central } \\
\text { database management } \\
\text { systems }\end{array}$ & $\begin{array}{l}\text { By cross-functional } \\
\text { teams based on core } \\
\text { competencies }\end{array}$ & $\begin{array}{l}\text { Based on analytical } \\
\text { and knowledge } \\
\text { management } \\
\text { capabilities }\end{array}$ \\
\hline
\end{tabular}

Figure 3. Partner / Customer Relationships \& Information / Decision Making Dimensions 


\begin{tabular}{|c|c|c|c|c|}
\hline Key element & Inception & Coordination & Innovation & Collaboration \\
\hline \multicolumn{5}{|c|}{ BUSINESS STRATEGY DIMESIONS } \\
\hline $\begin{array}{l}\text { Orientation I } \\
\text { Focus }\end{array}$ & $\begin{array}{l}\text { Narrow \& functionally } \\
\text { focused in a reactive } \\
\text { mode }\end{array}$ & $\begin{array}{l}\text { Information fow } \\
\text { efficiency, spanning } \\
\text { multiple business } \\
\text { processes }\end{array}$ & $\begin{array}{l}\text { Inter-enterprise } \\
\text { bustiess efficiency }\end{array}$ & $\begin{array}{l}\text { Broad-based } \\
\text { collaboration, customer } \\
\text { valoe }\end{array}$ \\
\hline Objectives & $\begin{array}{l}\text { Sales growth, cost } \\
\text { reduction }\end{array}$ & $\begin{array}{l}\text { Prioritized } \\
\text { lmprovements accross } \\
\text { the enterprise }\end{array}$ & $\begin{array}{l}\text { Best partaer } \\
\text { performance }\end{array}$ & $\begin{array}{l}\text { Dynamic network } \\
\text { competitire adrantage } \\
\text { (real-time visibility, } \\
\text { fevibility, customer } \\
\text { responsiveness) }\end{array}$ \\
\hline Business models & $\begin{array}{l}\text { Seller-driven, } \\
\text { product-driven, } \\
\text { functions-driven, pash } \\
\text { model (build-to-stock) }\end{array}$ & $\begin{array}{l}\text { Enterprise } \\
\text { yide-driven, push } \\
\text { model }\end{array}$ & $\begin{array}{l}\text { Bxtended enterprise, } \\
\text { pall model } \\
\text { (build-to-demand), } \\
\text { web-based services }\end{array}$ & $\begin{array}{l}\text { Virtual business } \\
\text { communities / } \\
\text { neturorks }\end{array}$ \\
\hline $\begin{array}{l}\text { Organizational } \\
\text { structure }\end{array}$ & $\begin{array}{l}\text { Departmental, } \\
\text { fragmented, partial }\end{array}$ & $\begin{array}{l}\text { Moltiple bosiness } \\
\text { precess mapping }\end{array}$ & $\begin{array}{l}\text { Aligament with } \\
\text { iater-enterprise } \\
\text { processes }\end{array}$ & $\begin{array}{l}\text { Virtual, rapidly } \\
\text { re-coufigurable, } \\
\text { dy wamic }\end{array}$ \\
\hline $\begin{array}{l}\text { Management } \\
\text { skills }\end{array}$ & $\begin{array}{l}\text { Deep funetional } \\
\text { expertise }\end{array}$ & $\begin{array}{l}\text { Soft skills, ability to } \\
\text { lead \& work in cross. } \\
\text { functional teams and in } \\
\text { multiple business } \\
\text { processes }\end{array}$ & $\begin{array}{l}\text { Focused on } \\
\text { inter-enterprise } \\
\text { precesses, extended } \\
\text { enterprise } \\
\text { management skilis }\end{array}$ & $\begin{array}{l}\text { Broad-based } \\
\text { collaboration, } \\
\text { integrated } \\
\text { organizational team } \\
\text { structures at multiple } \\
\text { levels }\end{array}$ \\
\hline
\end{tabular}

TECIINOLOGY DIMENSIONS

\begin{tabular}{|c|c|c|c|c|}
\hline $\begin{array}{l}\text { Use of e-business } \\
\text { capability }\end{array}$ & Low & Low & Bilgh & Full use \\
\hline Process models & Data-driven, bateh & Data-driven & $\begin{array}{l}\text { Data } 8 \text { basinass } \\
\text { logic-driven }\end{array}$ & Werkflow-bastd \\
\hline Software systems & $\begin{array}{l}\text { Legacy systems } \\
\text { Materials Requirement } \\
\text { Planning (MRP D }\end{array}$ & $\begin{array}{l}\text { MRP II, Enterprise } \\
\text { Resonrce Planning } \\
\text { (RRP), Distribution } \\
\text { Resource Planniag } \\
\text { (DRP) }\end{array}$ & $\begin{array}{l}\text { Extended BRP, } \\
\text { Pront-end Castorater } \\
\text { Relationship } \\
\text { Hanagement (CRM), } \\
\text { Partners Relationship } \\
\text { Mianagement (PRM), } \\
\text { Sapply Chaia } \\
\text { Management (SCM) }\end{array}$ & $\begin{array}{l}\text { Integrated e-Business } \\
\text { solutions, data \& web } \\
\text { mining systems, } \\
\text { analytical CRMI }\end{array}$ \\
\hline Methodologies & $\begin{array}{l}\text { Original methodologies } \\
\text { for reactive } \\
\text { performance \& cost } \\
\text { reduction }\end{array}$ & $\begin{array}{l}\text { Total Quality } \\
\text { Management (TQM), } \\
\text { Business Process } \\
\text { Reenginetring (BPR), } \\
\text { Activity-Based Costing } \\
\text { (ABC), Just-la-Time } \\
\text { (JIT) }\end{array}$ & $\begin{array}{l}\text { Emcient Consumer } \\
\text { Response (BCR), } \\
\text { Enterprise Applicatioa } \\
\text { Integration (EAD, } \\
\text { Integrated demand } \\
\text { forecasting, planaing } \\
\text { and scheduling }\end{array}$ & $\begin{array}{l}\text { Collaborative } \\
\text { Planning, Forecasting, } \\
\text { and Replenishment } \\
\text { (CPFR), knowledge } \\
\text { management (data \& } \\
\text { web nining } \\
\text { methodologies) }\end{array}$ \\
\hline Complexity & Low (legacy systems) & $\begin{array}{l}\text { Moderate (enterprise } \\
\text { systems) }\end{array}$ & $\begin{array}{l}\text { High (incompatible } \\
\text { system intertaces, } \\
\text { helerogeneoas } \\
\text { platforms \& external } \\
\text { systems, open } \\
\text { standards not } \\
\text { proliferated) }\end{array}$ & $\begin{array}{l}\text { High (inereased } \\
\text { senuantie diversity, } \\
\text { many flavors of } \\
\text { XML-schema ehaos) }\end{array}$ \\
\hline Architecture & Fat client & $\begin{array}{l}\text { Thin client, two or } \\
\text { three tier }\end{array}$ & Thin client, E-tler & $\begin{array}{l}\text { Open (XML), dynamic, } \\
\text { interactive }\end{array}$ \\
\hline $\begin{array}{l}\text { Structure of } \\
\text { information } \\
\text { exchange }\end{array}$ & $\begin{array}{l}\text { National and } \\
\text { industry-oriented EDI } \\
\text { data structures }\end{array}$ & $\begin{array}{l}\text { International BDI data } \\
\text { struetures }\end{array}$ & $\begin{array}{l}\text { Interaational BDI data } \\
\text { structures or national } \\
\text { and lodestry -oriented } \\
\mathrm{XML} \text { data structures }\end{array}$ & $\begin{array}{l}\text { International XNIL } \\
\text { data structures } \\
\text { (schemas) }\end{array}$ \\
\hline $\begin{array}{l}\text { Data } \\
\text { communication }\end{array}$ & $\begin{array}{l}\text { Point-to-point direct } \\
\text { connections }\end{array}$ & $\begin{array}{l}\text { Valoe-Added } \\
\text { Networks, Intranets, } \\
\text { Internet }\end{array}$ & Extranets, Internet & $\begin{array}{l}\text { Dymamic-rirtual } \\
\text { networks }\end{array}$ \\
\hline
\end{tabular}

Figure 4. Business Strategy \& Technology Dimensions 


\section{CONCLUSIONS}

In order to be competitive in today's global market, organizations need to forge tighter and closer working relationships with their supply chain partners. There is a need to automate processes across all of these partners and ensure that transactions flow quickly and securely between the different partners. Organizations must be able to extend their internal information systems beyond their boundaries and include their partners.

The Internet provides the organizations with the opportunity to achieve this the opportunity to transcend boundaries, leverage legacy resources and behave like a single virtual enterprise. It's use has evolved from initial website development (digital presence) toward leveraging the Internet for greater supply chain efficiencies through the development of exchanges, trading communities, and, ultimately, virtual and dynamic networks.

The new e-business models and technologies support the successful implementation of e-supply chain by breaking down barriers among business partners all along the supply chain.

Transforming the concepts of supply chain and e-commerce into a viable ebusiness strategy and model becomes critical to future success. Business strategy, partnership relationships, information/decision making and technology dimensions can be used in order to classify levels of supply chain transformation related to e-business evolution. The suggested Supply Chain Transformation Grid builds commercially viable supply chain levels to meet the requirements for future development or current evaluation of supply chain practice.

Although there are challenges to the implementation of the e-supply chain, the benefits derived from an integrated supply chain will overcome these challenges as companies come to realize the need for real-time information systems and adapt to new business models.

As organizations enter a new age of global competitiveness, electronic supply chain would serve as a tremendous catalyst for this new age and aid them in their quest for market share and profitability.

\section{REFERENCES}

Andersen, A., (2000), "Survey of customers purchasing products on-line in the USA", fourth quarter 1999, www.andersen.com

Burnes J., (1996), “Using ISCM to Create a Competitive Edge in the Year 2000”, Newsletter 40, MIT Center for Transportation Studies. 
Dobbs H., (1998), “Competition's New Battleground: The integrated Value Chain”, Cambridge Technology Partners.

Durchslag S., Donato G., Hagel J., (2001), "Web Services: Enabling the Collaborative Enterprise", Grand Central Networks Available from: URL: http://eserv.ebizq.net/wbs/donato_la.html

Ernst \& Young LLP. "The 3P retailing model: from presence to profits" [online] 1999 [cited 2000 May 15]. Available from: URL: http://www.ey.com/

Folinas D., Manthou V., Vlachopoulou M., (2001), "Logistics Service Management in Virtual Organization Environment: Modeling Systems and Procedures", 17th International Logistics Congress: Logistics from $\alpha$ to $\Omega$, Thessaloniki.

Gartner Group. E-business dimension model: clarity beyond the hype [online] 2000 [cited 2000 Dec 29]. Available from: URL: http://www.gartnerweb.com/public/static/hotc $100093980 . h t m l$

Hamel G., Prahaland G., (1990), "The core competencies of the corporation", Harvard Business Review, Watertown, MA, May-June.

Hinterhuber H., Levin M., (1994), "Strategic networks the organization of the future", Long Range Planning, Vol.27, No. 3, 43-53.

Hoek R., (2001), "E-supply chains - virtually non-existing” Supply Chain Management: An International Journal, 6:1, 21-28.

Kulin F., Rosenbaum B., (2000), "The Supply Chain Network @ Internet Speed", Amacom.

LaLonde B., (1998), "Supply Chain Evolution by the Numbers", Supply Chain Management Review, Spring.

Lipis L., Matthews K., “Express Marketplace: A Supply Chain Management eBusiness Solution”, [online] 2001 [cited 2001 November 1]. Available from: URL: http://ejigsaw.bitpipe.com/data/ detail id $=1005160773 \_375 \&$ type $=$ RES $\& x=83626829$.

Morath P., (2000), “Success @ e-business. Cambridge" (UK): Mc-Graw Hill Publishing Company.

Muzumdar M., Balachandran N., “The supply chain evolution", [online] 2001 [cited 2001 October 1]. Available from: URL: http://www.aspentech.com/corporate/press/ publications.cfm? pubid $=168 \&$ displaypub $=2$.

Pfohl H., Buse H., (2000), "Inter-Organizational Logistics Systems in Flexible Production Networks", International Journal of Physical Distribution \& Logistics Management, Vol.30, No. 5, 388-408.

Poirer C., Bauer M., (2001), "e-Supply Chain: using the Internet to revolutionize your business", Berrett-Kohler Publisher, Inc.

Poirer C., Reiter S., (1998), "Supply Chain Optimization: Building the Strongest Total Business Network", Berrett-Kohler Publisher, Inc.

Simchi-Levi D., Kaminsky P., Simchi-Levi E., (2000), "Designing and Managing the Supply Chain, Concepts, Strategies and Case Studies", Irwin McGraw-Hill.

Stein W., (2001), "Trading Partner Integration", KPMG Consulting.

Straus D., "Four Stages to Building an Effective Supply Chain Network", [online] 2002 [cited 2002 February 26]. Available from: URL: http://www.ebnonline.com/columns/ OEG20010223S0047-P.

Sydow J., (1996), "Flexible Specialization in Regional Networks", Staber, U.H, Schaefer, N.V, Sharma, B, Business Networks: Prospects for Regional Development, De Gruyter, Berlin, New York, NY, 24-40. 
Tan G.W., Shaw J., Fulkerson B., (2000), “Web-based Supply Chain Management” Information Systems Frontiers, 2:1, 41-55.

Vassos T., (1996) "Strategic internet marketing”, USA: Que Business Computer Library. 